\section{Environmental effect on sunflower oil quality}

\author{
Amadeu Regitano Neto $^{1^{*}}$, Ana Maria Rauen de Oliveira Mi- \\ guel $^{2}$, Anna Lúcia Mourad ${ }^{2}$, Ercília Aparecida Henriques² and \\ Rosa Maria Vercelino Alves ${ }^{2}$
}

\begin{abstract}
Sunflower is one of the most important oilseed crops and produces a high-quality edible oil. Balance of fatty acids in standard sunflower oil shows preponderance of linoleic rather than oleic acid, and conditions during seed development, such as temperature, changes the oleic/linoleic ratio of the oil. This work aimed to evaluate the environmental effect on fatty acid profile in a group of standard and high oleic varieties and hybrids. Seeds were produced during regular season crop and during off-season crop featuring different temperatures from anthesis to maturity. Fatty acid composition was determined by gas chromatography. Levels of oleic acid, in standard oil genotypes, raised as the crop developed in warmer environment while levels of linoleic acid decreased, and the opposite was observed when the crop was grown under lower temperature. High oleic genotypes were less sensitive to environment switching and showed lower variation on fatty acid composition.
\end{abstract}

Key words: Helianthus annuus, high oleic, fatty acid, genotype x environment interaction.

\section{INTRODUCTION}

Sunflower cultivation plays a key role in edible oil production worldwide, represents an important alternative for crop rotation and provides intercropping and succession in producing regions. In Brazil, sunflower production is concentrated in the second crop, during summer-fall period. The production in 2014/15 crop will reach 189.7 thousand tons and the state of Mato Grosso, the major producer, is responsible for $85 \%$ of Brazilian sunflower production (Conab 2015).

Fatty acid (FA) composition of sunflower seed lipids is determined by plant genotype and depending on it, this composition is more or less affected by environmental conditions such as light and temperature (Schulte et al. 2013).

Traditional sunflower genotypes produce high quality edible oil with low content of saturated fatty acids, about $100 \mathrm{~g} \mathrm{~kg}^{-1}$ of palmitic (16:0) and stearic acid (18:0) and elevated concentration (up to $90 \%$ ) of unsaturated FA, mainly 18:1 and 18:2, with the predominance of linoleic acid (18:2) (Rodriguez et al. 2002). Breeding efforts have conducted to the release of genotypes with much higher concentration of oleic acid rather than linoleic acid. Stable high oleic (HO) genotypes were developed through induced mutation by Soldatov (1976) and are nowadays present in a wide range of hybrids (Fernández-Martínez et al. 2007).

Following this trend, other variants have been produced such as high stearic or high palmitic acid cultivars (Fernández-Moya et al. 2005, Skorić et al. 2008).
Crop Breeding and Applied Biotechnology 16: 197-204, 2016 Brazilian Society of Plant Breeding. Printed in Brazil http://dx.doi.org/10.1590/1984$70332016 v 16 n 3 a 30$

(20)

(1)




\section{A Regitano Neto et al.}

FA composition of the oil determines its use (Metzger and Bornscheuer 2006). Multiple applications have been identified for the new FA profiles such as pharmaceutical, cosmetic, industrial or edible use (Gupta 2014).

Although traditional sunflower genotypes produce high quality oil for cooking, the development of HO sunflower genotypes represents a very important breeding achievement. The largest advantage of this type of oil is its higher degree of oxidative stability than traditional sunflower oils with standard oleic acid concentration (Grompone 2005).

The effect of temperature during the plant cycle, mainly from anthesis to maturity, on the FA composition of sunflower oil has been reported to change the oleic/linoleic acid $(\mathrm{O} / \mathrm{L})$ ratio, known as unsaturation ratio, in the oil. Oil content and composition are modified by high constant temperature during sunflower grain development, and previous reports indicated a marked reduction in the percentage of linoleic acid in standard sunflower oil, apparently due to the effect of temperature on the activity of the enzyme oleate desaturase, which is responsible for the conversion of oleic to linoleic acid (Flagella et al. 2002, Grompone 2005). Garcés and Mancha (1991), who established that the oleyl-phosphatidylcholine-desaturase activity, in sunflower, is inhibited at temperatures above $20{ }^{\circ} \mathrm{C}$, specifically investigated this effect and Rolletschek et al. (2007), afterwards, demonstrated the mechanism by which temperature modifies the unsaturation degree of the sunflower oil through its effect on dissolved oxygen levels in the developing seed.

Substantial changes are reported for standard genotypes, while less significant changes in the unsaturation ratio have been observed in $\mathrm{HO}$ genotypes influenced by temperature (Flagella et al. 2002, Izquierdo and Aguirrezábal 2008, Grunvald et al. 2013, Piao et al. 2014).

In Brazil, mainly in southeastern and western states, it became an usual practice to take advantage of the mild climate and the still occurring rains to sow the off-season crop, which represents a second opportunity for sowing, just subsequent to the crop season. Crop season takes place during spring/summer and off-season crop in summer-fall period. These two periods present a very diverse environment in terms of temperature during crop development, with anthesis occurring in summer and fall, respectively. The State of Mato Grosso is the largest national sunflower producer and even presenting a tropical climate, the temperature during plant development is quite distinct between the two adopted sowing periods.

The aim of this work was to investigate the effect of sowing date and consequently the effect of temperature on oil yield and FA composition of seeds from standard and HO sunflower hybrids grown in southeastern Brazil.

\section{MATERIAL AND METHODS}

Sunflower seeds were supplied by seed producers and comprised four open pollinated varieties, six single cross hybrids and three three-way cross hybrids of standard sunflower and two HO three-way cross hybrids that are listed in Table 1.

Table 1. Description of genotypes

\begin{tabular}{|c|c|c|c|c|}
\hline Cultivars & Genotype structure & Oil (\%) & Oil type & Seed color \\
\hline Catissol & open population & $30-40 \%$ & standard & black \\
\hline $\mathrm{ClA}$ & open population & $38-44 \%$ & standard & black \\
\hline larama & open population & $38-42 \%$ & standard & gray \\
\hline Uruguai & open population & $28-35 \%$ & standard & gray stripped \\
\hline AG 975 & single cross hybrid & $45-50 \%$ & standard & black \\
\hline Aguará 6 & single cross hybrid & $45-50 \%$ & standard & black \\
\hline Helio 250 & single cross hybrid & $44-48 \%$ & standard & black \\
\hline Helio 251 & single cross hybrid & $40-44 \%$ & standard & gray stripped \\
\hline Helio 253 & single cross hybrid & $42-46 \%$ & standard & gray stripped \\
\hline Helio 358 & single cross hybrid & $44-55 \%$ & standard & black \\
\hline AG 962 & three-way cross hybrid & $43-50 \%$ & standard & black \\
\hline Charrua & three-way cross hybrid & $45-50 \%$ & standard & black \\
\hline Helio 360 & three-way cross hybrid & $43-47 \%$ & standard & gray stripped \\
\hline Olisun 3 & three-way cross hybrid & $45-50 \%$ & high oleic & black \\
\hline Olisun 5 & three-way cross hybrid & $45-50 \%$ & high oleic & black \\
\hline
\end{tabular}


In order to obtain the grain samples for analysis, the commercial seeds were sown in two consecutive years during offseasons (2011 and 2012) and during regular seasons (2011/12 and 2012/13) at the IAC Experimental Center (Agronomic Institute, Farm Santa Elisa) in Campinas, SP, Brazil (lat $22^{\circ} 52^{\prime} \mathrm{S}$, long $47^{\circ} 05^{\prime} \mathrm{W}$, and alt $660 \mathrm{~m}$ asl). Cultivation practices were the same over the four field assays and comprised liming, sowing fertilization (300 kg ha-1 of 8-28-16), stand (40000 plants ha ${ }^{-1}$ ) and top dressing ( $40 \mathrm{~kg} \mathrm{ha}^{-1}$ of $\mathrm{N}$ ) with $1 \mathrm{~kg} \mathrm{ha}^{-1}$ of boron at 30 days from germination. Weeds were hoed when necessary and no agrochemicals were needed in these fields.

The plants were harvested and aquenes were detached from sunflower heads after drying. Grain samples were processed for total lipids and FA composition analysis at the Institute of Food Technology in Campinas, SP, Brazil. The samples were ventilated and grains were homogenized in a Tecnal, model TE-631/2 multipurpose mill with water circulation. A weighted sample of $5 \pm 0.5 \mathrm{~g}$ was taken of each genotype, placed in a double paper filter cartridge and submitted to an organic solvent-based extraction, with petroleum ether $(80 \mathrm{~mL})$ as the extraction solvent in a Butt-type extraction equipment ( 8 hours). The cartridge was discarded and the miscela (oil + solvent) was separated by rotary evaporation $\left(40-50^{\circ} \mathrm{C}\right)$. The residual solvent was eliminated by current of nitrogen and the balloon containing the lipids was maintained in a drying oven at $100 \pm 5^{\circ} \mathrm{C}$ for 1 hour, cold and weighted. The percentage of oil in the seeds was then determined by gravimetric measurement of the collected oil and expressed as a weight percent relative to the initial weight of the oilseeds (Firestone 2008). All analyses were performed in duplicate.

Compositions in FA were determined by the method of gas chromatography with capillary column and detection by flame ionization. The samples were prepared following the obtainment of FAME (fatty acid methyl ester) according to Hartman and Lago (1973), and the identification of FA was performed by a gas chromatograph Varian, model 3900, and capillary column by a Chrompack CP-Sil 88. The FA was identified by its time of retention, and chromatograms were compared to well-known commercial standards and quantification was accomplished as a relative percentage of area, as suggested by Firestone (2008).

Data set from 15 genotypes $(G)$, sowed for two years (Y) in two sowing dates (SD) each, were analyzed through analysis of variance (ANOVA) in a completely randomized block design with two replications. Joint ANOVAs were performed for each FA and for oil content considering mathematical model Yijk = $m+G i+Y j+S D k+G Y i j+G S D i k+Y S D j k+G Y S D i j k+E i j k$, with $Y$ of random effect. Treatment means were compared by Tukey's test $(p<0.05)$. Coefficients of determination $\left(R^{2}\right)$ were calculated to access proportional contribution of genotype interactions ( $G \times Y, G \times S D, G \times Y \times S D)$ to total genotype $x$ environment interaction using related sum of squares. Coefficients of correlation were estimated with respective $p$-values, indicating the probability of observing the correlation coefficient under the null hypothesis or no correlation, with $n-2$ degrees of freedom. Analyses were performed using SAS software (2016).

\section{RESULTS AND DISCUSSION}

Mean lipid concentrations largely varied among genotypes and sowing dates (Table 2). The cultivar Uruguai, developed by IAC, was not designed for oil production, but bird food or silage, and presented the lowest oil concentration for all sowing dates ( 25.6 and $26.4 \%$ ) in relation to any other genotype. Oil concentration from conventional oil hybrids ranged from $31.9 \%$ (Helio 251) to $47.0 \%$ (Helio 358 ) in summer-fall plantings and from $28.5 \%$ (Helio 253) to $45.3 \%$ (Helio 358 ) in spring-summer crop. HO three-way hybrids produced more oil (42.85 and $44.48 \%)$ during season crop than during offseason crop (38.3 and 39.4\%). Lipid concentration mean squares (MS) (Table 4) showed significant differences $(p<0.05)$ for all sources of variation, except for $Y \times S D$ interaction. Considering all genotype $x$ environment interactions for lipid content, estimated coefficient of determination $\left(R^{2}\right)$ indicated the largest contribution of $G \times Y(45.0 \%)$ interaction along with $\mathrm{G} \times \mathrm{SD}(28.8 \%)$ and $\mathrm{G} \times \mathrm{Y} \times \mathrm{SD}(26.0 \%)$ to estimated sum of squares.

These results are consistent and expected, since genotypes have diverse genetic background on hybrid formation and were selected and meant for planting on different locations (Table 1). Moreover, environment conditions during cultivation, considering $Y$ and SD were distinct, regarding temperature and water availability, although no water deficit occurred during these periods (Table 5). Lipid concentration showed no significant coefficient of correlation with FA and temperatures (Table 6) considering standard oil genotypes. Lipids concentration of HO hybrids showed significant negative correlation with stearic acid while all other coefficients were not significant. In a different environmental condition, Onemli (2012), evaluating conventional hybrid, reported strong correlation of oil content and oleic (-0.84), linoleic (0.84) 


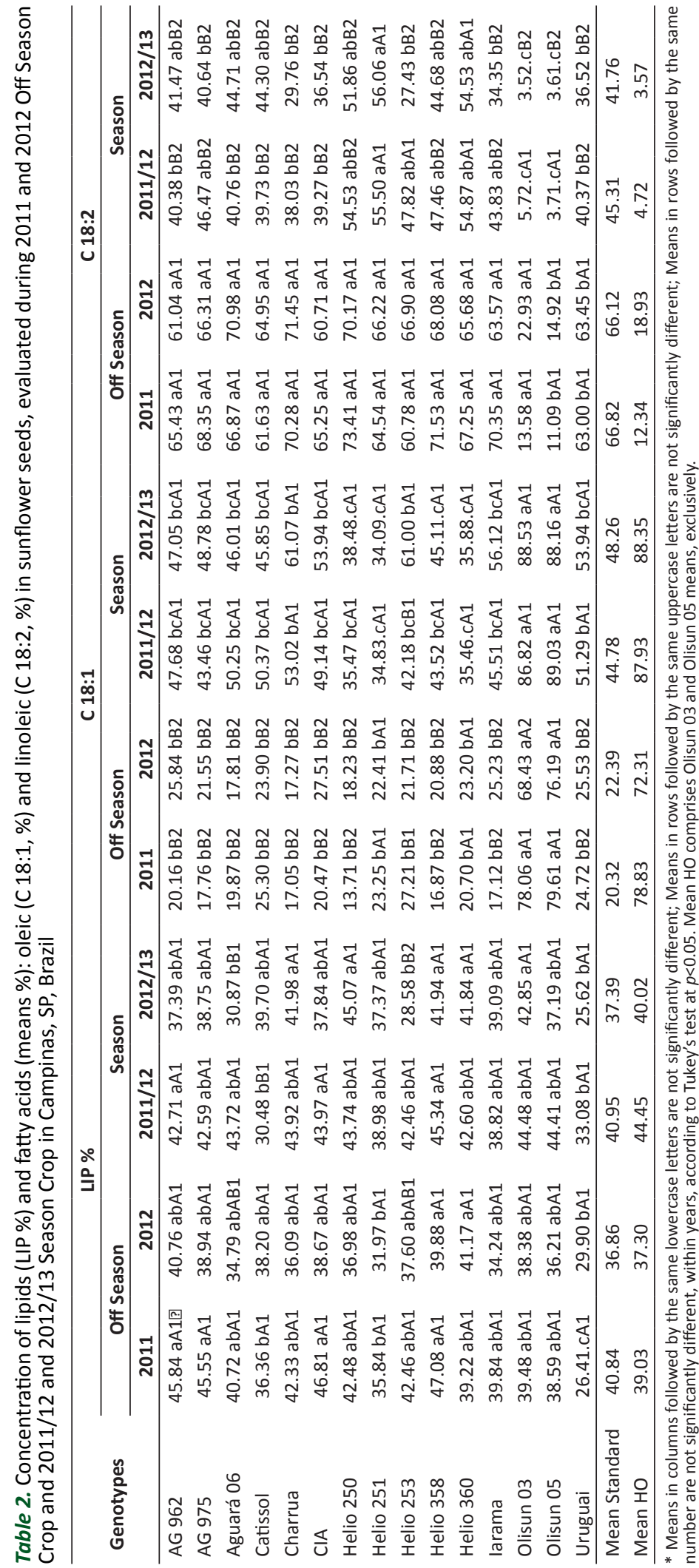

and palmitic acid (0.93) concentration.

Means of total saturated FA (TSFA) comprising concentrations of myristic (C14:0), palmitic (C16:0), stearic (C18:0), arachidic (C20:0), behenic (C22:0) and lignoceric (C24:0) FA summed (Table 3), ranged, in season crop, from 8.09 to $11.59 \%$ in standard genotypes and from 6.86 to $7.84 \%$ in $\mathrm{HO}$ hybrids. In off-season crop TSFA concentrations were between 10.71 and $14.14 \%$ in conventional genotypes and between 7.97 and $8.92 \%$ in $\mathrm{HO}$ hybrids. Major contribution to TSFA content were given by palmitic and stearic acids, and although standard oil genotypes had higher TSFA means when compared to $\mathrm{HO}$ oils, concentrations of TSFA in both types showed a tendency to be slightly lower when sunflower were cultivated in warmer environments.

Significant coefficients of correlation (Table 6) between palmitic acid and stearic acid were low and positive (0.296), while between palmitic and oleic were moderate and negative $(-0.610)$ and moderate positive $(0.609)$ between palmitic and linoleic acid. For stearic acid correlations with oleic (-0.459) and linoleic acid (0.413) significant coefficients were found in standard genotypes. Correlations of palmitic and stearic acids in $\mathrm{HO}$ hybrids showed not significant coefficients for all traits. Such effect could be attribute to the small sample size $(\mathrm{N}=8)$ used for the estimates. Although not significant, such correlations with oleic and linoleic acids showed the same magnitude and direction observed for conventional oil genotypes.

ANOVA of TSFA percentage (Table 4) showed significant differences for all sources of variation, except for a non-significant triple interaction, indicating that the effect of $\mathrm{G} \times \mathrm{Y}$ and $\mathrm{G} \times \mathrm{SD}$ were responsible for 32.31 and $27.14 \%$, respectively, of total $\mathrm{G} \times \mathrm{E}$ interactions.

The effect of the environment on sunflower saturated FA concentration has been reported (Izquierdo and Aguirrezábal 2008, Piao et al. 2014) and attributed to planting date (Zheljazkov et. al. 2009), night temperature (Izquierdo et al. 2002) and hybrids (Zheljazkov et al. 2011). This indicates the possibility of producing sunflower oil with improved dietary characteristics through cultivar selection and management of the environment in which the crop will develop by choosing more adequate SD. 
Content of total unsaturated fatty acids (TUFA) in all studied sunflower oils revealed broad range of variation among genotypes (Table 3). Oleic and linoleic acids summed, from standard genotypes, showed concentrations ranging from 85.78\% (AG 962) to 89.26\% (Uruguai) in off-season plantings and from 88.27\% (AG 962) to 91.92\% (Uruguai) in regular season plantings. Considering HO hybrids, TUFA levels were $91.08 \%$ (Olisun 5 ) and $92.03 \%$ (Olisun 3 ) in off-season crop and from $92.16 \%$ to 93.12 in Olisun 5, in season crop. In average, all studied genotypes had higher TUFA content when plant cycle occurred during the warmer environment.

Oleic acid contents were different among standard but were not among HO genotypes (Table 2). Observed levels of oleic acid for standard genotypes were from $13.71 \%$ (Helio 250) to $27.51 \%$ (CIA) during off-season crop and from $34.09 \%$ (Helio 251) to $61.07 \%$ (Charrua) in season crop. For HO genotypes, concentrations of oleic acid were between $68.43 \%$ (Olisun 3 ) and $79.61 \%$ (Olisun 5) in off-season crop, and from $86.82 \%$ (Olisun 3 ) to $89.03 \%$ (Olisun 5 ) in season crop.

Observed levels of linoleic acid (Table 2), in its turn, varied in off-season crop from $60.78 \%$ (Helio 253 ) to $73.41 \%$ (Helio 250) and in season crop from $27.43 \%$ (Helio 253) to 56.06\% (Helio 251) among standard genotypes, while in HO hybrids were $11.09 \%$ (Olisun 5) and $22.93 \%$ (Olisun 3 ) in off-season crop, and $3.71 \%$ (Olisun 5 ) and $5.72 \%$ (Olisun 3 ) in season crop.

Table 3. Concentration means of total saturated fatty acids (TSFA, mean \%) and total unsaturated fatty acids (TUFA, mean \%) evaluated during 2011 and 2012 Off Season Crop and 2011/12 and 2012/13 Season Crop in Campinas, SP, Brazil

\begin{tabular}{|c|c|c|c|c|}
\hline \multirow{2}{*}{ Genotypes } & \multicolumn{2}{|c|}{ TSFA } & \multicolumn{2}{|c|}{ TUFA } \\
\hline & Off Season & Season & Off Season & Season \\
\hline AG 962 & $13.53 \mathrm{aA} *$ & $11.36 \mathrm{aB}$ & $86.43 \mathrm{cB}$ & $88.57 \mathrm{dA}$ \\
\hline AG 975 & $12.82 \mathrm{abA}$ & $10.12 \mathrm{bcB}$ & $87.18 \mathrm{cB}$ & $89.88 \mathrm{cA}$ \\
\hline Aguará 06 & $11.93 \mathrm{bA}$ & $8.79 c B$ & $88.03 \mathrm{bcB}$ & $91.18 \mathrm{bA}$ \\
\hline Catissol & $12.80 \mathrm{abA}$ & $10.22 \mathrm{bcB}$ & $87.20 \mathrm{cB}$ & $89.67 \mathrm{cdA}$ \\
\hline Charrua & $11.80 \mathrm{bA}$ & $9.44 \mathrm{bcB}$ & 88.20 bcB & $90.46 \mathrm{bcA}$ \\
\hline Helio 251 & $11.50 \mathrm{bA}$ & $9.46 \mathrm{bcB}$ & 88.49 bB & $90.54 \mathrm{bcA}$ \\
\hline Helio 253 & $11.50 \mathrm{bA}$ & $10.35 \mathrm{bB}$ & $88.53 \mathrm{bA}$ & $89.53 \mathrm{cdA}$ \\
\hline Helio 358 & $11.04 \mathrm{bA}$ & $9.12 \mathrm{cB}$ & 88.96 bB & 90.66 bcA \\
\hline Helio 360 & $11.30 \mathrm{bA}$ & $9.36 \mathrm{bcB}$ & $88.70 \mathrm{bB}$ & $90.64 \mathrm{bcA}$ \\
\hline larama & $11.57 \mathrm{bA}$ & $9.62 \mathrm{bcB}$ & $88.40 \mathrm{bcB}$ & $90.21 \mathrm{bcA}$ \\
\hline Mean Standard & 11.91 & 9.58 & 88.08 & 90.33 \\
\hline Mean HO & 8.39 & 7.21 & 91.61 & 92.67 \\
\hline
\end{tabular}

* Means in columns followed by the same lowercase letters are not significantly different; Means in rows followed by the same uppercase letters are not significantly different, according to Tukey's test at $p<0.05$. Mean $\mathrm{HO}$ comprises Olisun 03 and Olisun 05 means, exclusively.

Table 4. Mean Squares (MS) and p-values from joint ANOVA of oil yield (Oil, \%), oleic acid (C 18:1, \%) and linoleic acid (C 18:2, \%), total saturated FA (TSFA, \%) and total unsaturated FA (TUFA, \%) in Campinas, SP, Brazil

\begin{tabular}{|c|c|c|c|c|c|c|c|c|c|c|c|}
\hline \multirow{2}{*}{ Sources } & \multirow{2}{*}{ df } & \multicolumn{2}{|c|}{ Oil } & \multicolumn{2}{|c|}{ C18:1 } & \multicolumn{2}{|l|}{ C18:2 } & \multicolumn{2}{|l|}{ TSFA } & \multicolumn{2}{|c|}{ TUFA } \\
\hline & & MS & $p$ & MS & $p$ & MS & $p$ & MS & $p$ & MS & $p$ \\
\hline Genotypes (G) & 14 & 109.59 & 0.00 & 2387.48 & 0.00 & 2137.50 & 0.00 & 11.97 & 0.00 & 11.83 & 0.00 \\
\hline Years (Y) & 1 & 406.42 & 0.00 & 118.94 & 0.00 & 66.81 & 0.02 & 9.15 & 0.00 & 9.70 & 0.00 \\
\hline Sowing Date (SD) & 1 & 20.20 & 0.04 & 16546.56 & 0.00 & 13737.97 & 0.00 & 141.91 & 0.00 & 131.00 & 0.00 \\
\hline$G \times Y$ & 14 & 28.76 & 0.00 & 31.18 & 0.00 & 28,51 & 0.01 & 1.00 & 0.00 & 1.11 & 0.00 \\
\hline $\mathrm{G} \times \mathrm{SD}$ & 14 & 18.42 & 0.00 & 126.82 & 0.02 & 115.80 & 0.00 & 0.84 & 0.00 & 0.93 & 0.00 \\
\hline $\mathrm{CV} \%$ & & 5.42 & & 8.77 & & 6.96 & & 3.88 & & 0,48 & \\
\hline Mean & & 39.17 & & 40.32 & & 48.98 & & 10.35 & & 89.60 & \\
\hline
\end{tabular}




\section{A Regitano Neto et al.}

ANOVA of oleic and linoleic acid (Table 4), presented significant $(p<0.05)$ MS for all sources of variation, except for a not significant $Y \times$ SD interaction for oleic acid. Proportional contribution to $G \times E$ sum of squares showed the preponderance of the genotype $x$ sowing date interaction, with coefficients of determination $\left(R^{2}\right)$ of 67.04 and $64.47 \%$ for oleic and linoleic acids levels. $G \times Y$ interaction had $R^{2}$ of 16.48 and $15.87 \%$ while triple interaction contributed with 15.16 and $16.05 \%$ for total interaction, for unsaturated acids in the same order. Oil content and FA composition have been shown to be significantly influenced by the environment and significant $\mathrm{G} \times \mathrm{E}$ interaction has been reported (Qadir et al. 2006, Van Der Merwe et al. 2013).

As expected, significant and negative coefficient of correlation (Table 6) was found between oleic and linoleic acid concentrations in standard (-0.997) and HO (-0.997) genotypes, as reported by Onemli (2012), who found a strong negative correlation estimate $(-0.99)$ between oleic and linoleic acids percentage.

Presented data corroborates with data from literature reports. Levels of oleic and linoleic acids in sunflower oil have been shown to vary according to temperature after flowering and variation in the oleic acid content to be inversely proportional to variation in the linoleic content (Ungaro et al. 1997, Qadir et al. 2006, Roche et al. 2006, Izquierdo and Aguirrezábal 2008, Turhan et al. 2010, Grunvald et al. 2013, Van Der Merwe et al. 2013, Piao et al. 2014). All the authors found the highest oleic acid content when crops were cultivated in warmer environments with higher temperature during seed development, and conversely, linoleic acid content increased when the crop developed under colder environments. The observed effect of temperature on the oleic/linoleic ratio in sunflower oil has been attributed to the synthesis or activity of the oleate desaturase enzyme, which is stimulated by low temperature and repressed by high temperature (Sarmiento et al. 1998, Flagella et al. 2002).

The more expressive differences between oleic and linoleic acid concentration due to temperature were observed in standard oil genotypes. Oleic acid content varied, in average (Table 2), from 21.36 to $46.52 \%$ and inversely linoleic acid content ranged from 66.47 to $43.53 \%$ from colder to warmer environments. HO genotype oils, in turn, showed less

Table 6. Mean Pearson's coefficient of correlation and respective $p$-values for lipids concentration, fatty acids* and temperatures for standard genotypes (above diagonal, $\mathrm{N}=52$ ) and high oleic hybrids (below diagonal, $\mathrm{N}=8$ )

\begin{tabular}{|c|c|c|c|c|c|c|c|c|}
\hline & LIP \% & C16:0 & C18:0 & C18:1 & C18:2 & TMax & TMean & TMin \\
\hline LIP \% & & $\begin{array}{c}-0.067 \\
0.637\end{array}$ & $\begin{array}{l}0.028 \\
0.844\end{array}$ & $\begin{array}{c}-0.132 \\
0.351\end{array}$ & $\begin{array}{l}0.126 \\
0.375\end{array}$ & $\begin{array}{l}0.027 \\
0.848\end{array}$ & $\begin{array}{c}-0.001 \\
0.996\end{array}$ & $\begin{array}{c}-0.031 \\
0.829\end{array}$ \\
\hline C16:0 & $\begin{array}{c}-0.119 \\
0.779\end{array}$ & & $\begin{array}{l}0.296 \\
0.033\end{array}$ & $\begin{array}{l}-0.610 \\
<.0001\end{array}$ & $\begin{array}{c}0.609 \\
<.0001\end{array}$ & $\begin{array}{l}-0.523 \\
<.0001\end{array}$ & $\begin{array}{l}-0.539 \\
<.0001\end{array}$ & $\begin{array}{l}-0.549 \\
<.0001\end{array}$ \\
\hline C18:0 & $\begin{array}{c}-0.800 \\
0.017\end{array}$ & $\begin{array}{c}-0.166 \\
0.695\end{array}$ & & $\begin{array}{c}-0.459 \\
0.001\end{array}$ & $\begin{array}{l}0.413 \\
0.002\end{array}$ & $\begin{array}{l}-0.533 \\
<.0001\end{array}$ & $\begin{array}{l}-0.560 \\
<.0001\end{array}$ & $\begin{array}{l}-0.583 \\
<.0001\end{array}$ \\
\hline C18:1 & $\begin{array}{l}0.606 \\
0.111\end{array}$ & $\begin{array}{c}-0.657 \\
0.077\end{array}$ & $\begin{array}{c}-0.560 \\
0.149\end{array}$ & & $\begin{array}{l}-0.997 \\
<.0001\end{array}$ & $\begin{array}{c}0.900 \\
<.0001\end{array}$ & $\begin{array}{c}0.910 \\
<.0001\end{array}$ & $\begin{array}{c}0.908 \\
<.0001\end{array}$ \\
\hline C18:2 & $\begin{array}{c}-0.562 \\
0.147\end{array}$ & $\begin{array}{l}0.690 \\
0.058\end{array}$ & $\begin{array}{l}0.504 \\
0.203\end{array}$ & $\begin{array}{l}-0.997 \\
<.0001\end{array}$ & & $\begin{array}{l}-0.887 \\
<.0001\end{array}$ & $\begin{array}{l}-0.893 \\
<.0001\end{array}$ & $\begin{array}{l}-0.888 \\
<.0001\end{array}$ \\
\hline TMax & $\begin{array}{l}0.617 \\
0.103\end{array}$ & $\begin{array}{c}-0.352 \\
0.392\end{array}$ & $\begin{array}{c}-0.754 \\
0.031\end{array}$ & $\begin{array}{l}0.920 \\
0.001\end{array}$ & $\begin{array}{c}-0.904 \\
0.002\end{array}$ & & $\begin{array}{c}0.994 \\
<.0001\end{array}$ & $\begin{array}{c}0.977 \\
<.0001\end{array}$ \\
\hline TMean & $\begin{array}{l}0.601 \\
0.115\end{array}$ & $\begin{array}{c}-0.306 \\
0.460\end{array}$ & $\begin{array}{c}-0.782 \\
0.022\end{array}$ & $\begin{array}{l}0.889 \\
0.003\end{array}$ & $\begin{array}{c}-0.870 \\
0.005\end{array}$ & & & $\begin{array}{c}0.994 \\
<.0001\end{array}$ \\
\hline TMin & $\begin{array}{l}0.576 \\
0.135\end{array}$ & $\begin{array}{c}-0.254 \\
0.544\end{array}$ & $\begin{array}{c}-0.803 \\
0.016\end{array}$ & $\begin{array}{l}0.846 \\
0.008\end{array}$ & $\begin{array}{c}-0.825 \\
0.012\end{array}$ & & & \\
\hline
\end{tabular}

" Fatty acids: C16:0 = palmitic acid, C18:0 = stearic acid, C18:1 = oleic acid, C18:2 = linoleic acid; TMax, TMean and TMin - average of maximum, mean and minimum temperatures during grain filling. 
expressive change in unsaturated acid percentage, and oleic acid, in average, increased from 75.57 to $88.14 \%$ and linoleic acid diminished from 15.63 to $4.14 \%$, when cultivation occurred in colder and warmer environments, respectively. The less expressive effect of temperature on oleic and linoleic acids concentration of HO hybrids has been reported (Flagella et al. 2002, Izquierdo and Aguirrezábal 2008, Grunvald et al. 2013, Van Der Merwe et al. 2013). This effect has been attributed to the activity of the oleate desaturase, limited to the early stage of the embryo development (Garcés and Mancha 1991) and also that its transcript is not accumulated during grain filling (Lagravère et al. 2004).

Most expressive changes in unsaturation ratio among standard oil genotypes due to moving sowing dates from colder to warmer environment, were observed in Charrua, which increased O/L ratio 6.95 times, from 0.24 to 1.68 , followed by Aguará 06 (4.12 times) and larama (4.11 times) changing from 0.27 and 0.32 in off season crop to 1.13 and 1.30 in season crop, respectively. Less expressive changes in O/L ratio were observed in Helio 251 (1.77 times) and Helio 360 (1.99 times), switching from 0.35 and 0.33 to 0.62 and 0.65 , in the same order. Changes in $\mathrm{HO}$ genotypes were from 4.01 to 18.98 in Olisun 03 (4.73 times) and from 5.99 to 24.19 in Olisun 05 (4.04 times).

Taken into account the sunflower crop productivity in Brazilian largest producer state, about $1500 \mathrm{~kg} \mathrm{ha}^{-1}$ (Conab 2015) along with industry preferences and possible rewarding, using these results, one must consider that conventional hybrids planted in the season crop (spring-summer) will produce $377.33 \mathrm{~kg} \mathrm{ha}^{-1}$ more oleic acid than the one planted in the off-season crop, while in opposite direction, the production of linoleic acid would be $344.04 \mathrm{~kg} \mathrm{ha}^{-1}$ greater when planted in the off-season crop.

In these same conditions, $\mathrm{HO}$ hybrids would produce $1322.05 \mathrm{~kg} \mathrm{ha}^{-1}$ of oleic acid during season crop, decreasing $188.46 \mathrm{~kg} \mathrm{ha}^{-1}$ with a raise of $172.35 \mathrm{~kg} \mathrm{ha}^{-1}$ of linoleic acid when sowed in off-season crop.

High levels of oleic acid in oils are related to longer shelf life due to their higher stability and resistance to oxidation. Oil industry and sunflower producers can take advantage of the temperature effects on FA synthesis by managing genotypes and sowing dates in order to have the best response for their needs.

\section{ACKNOWLEDGEMENTS}

Authors acknowledge the financial support of the National Counsel of Technological and Scientific Development (CNPq 555877/2010/8).

\section{REFERENCES}

Ciiagro (2015) Centro integrado de informações agrometeorológicas [homepage on the internet]. São Paulo: Instituto Agronômico; 19882003. Available at <http://www.ciiagro.sp.gov.br/ciiagroonline> Accessed on April 20, 2015.

Conab - Companhia Nacional de Abastecimento (2015) Acompanhamento da safra brasileira de grãos v.2 - Safra 2014/15, n.8 - Oitavo Levantamento. Conab, Brasília, 118p.

Fernández-Martínez JM, Pérez-Vich B, Velasco L and Domínguez J (2007) Breeding for specialty oil types in sunflower. Helia 30: 75-84.

Fernández-Moya V, Martínez-Force E and Garcés R (2005) Oils from improved high stearic acid sunflower seeds. Journal of Agricultural and Food Chemistry 53: 5326-5330.

Firestone $D$ (2008) Official methods and recommended practices of the American Oil Chemists Society. AOCS Press, Champaign, 1200p.

Flagella Z, Rotunno T, Tarantino E, Caterina RD and Caro AD (2002) Changes in seed yield and oil fatty acid composition of high oleic sunflower (Helianthus annuus L.) hybrids in relation to the sowing date and the water regime. European Journal of Agronomy 17: 221-230.
Garcés R and Mancha M (1991) In vitro oleate desaturase in developing sunflower seeds. Phytochemistry 30: 2127-2130.

Grompone MA (2005) Sunflower oil. In Shahidi F (ed) Bailey's industrial oil \& fat products-edible oils and fat products: edible oils. John Wiley \& Sons, Hoboken, p. 655-730.

Grunvald AK, Carvalho CGP, Leite RS, Mandarino JMG, Andrade CAD, Amabile RF and Godinho VDC (2013) Influence of temperature on the fatty acid composition of the oil from sunflower genotypes grown in tropical regions. Journal of the American Oil Chemists Society 90: 545-553.

Gupta MK (2014) Sunflower oil: history, applications and trends. Lipid Technology 26: 260-263.

Hartman L and Lago RCA (1973) Rapid preparation of fatty acid methyl from lipids. Laboratory Practice 22: 475-473.

Izquierdo NG, Aguirrezábal LAN, Andrade F and Pereyra V (2002) Night temperature affects fatty acid composition in sunflower oil depending on the hybrid and the phenological stage. Field Crops Research 77: 115-126.

Izquierdo NG and Aguirrezábal LAN (2008) Genetic variability in the response of fatty acid composition to minimum night temperature 


\section{A Regitano Neto et al.}

during grain filling in sunflower. Field Crops Research 106: 116-125.

Lagravère $T$, Kleiber $D$, Surel $O$, Calmon A, Bervillé $A$ and Dayde $J$ (2004) Comparison of fatty acid metabolism of two oleic and one conventional sunflower hybrids: A new hypothesis. Journal of Agronomy and Crop Science 190: 223-229.

Metzger JO and Bornscheuer U (2006) Lipids as renewable resources: current state of chemical and biotechnological conversion and diversification. Applied Microbiology and Biotechnology 71: 13-22.

Onemli F (2012) Impact of climate changes and correlations on oil fatty acids in sunflower. Pakistan Journal of Agricultural Science 49: 455-458.

Piao X, Choi SY, Jang YS, So YS, Chung JW, Lee S, Jong J and Kim HS (2014) Effect of genotype, growing year and planting date on agronomic traits and chemical composition in sunflower (Helianthus annuus L.) germplasm. Plant Breeding and Biotechnology 2: 35-47.

Qadir G, Ahmad S, Hassan F and Cheema MA (2006) Oil and fatty acid accumulation in sunflower as influenced by temperature variation. Pakistan Journal of Botany 38: 1137-1147.

Rodriguez DJ, Philips DBS, Rodriguez-Garcia R and Angulo-Sanchez JL (2002) Grain yield and fatty acid composition of sunflower seed for cultivars developed under dry land conditions. In Janick J and Whipkey A (eds) Trends in new crops and new uses. American Society for Horticultural Science Press, Alexandria, p. 139-142.

Roche J, Bouniols A, Mouloungui Z, Barranco T and Cerny M (2006) Management of environmental crop conditions to produce useful sunflower oil components. European Journal of Lipid Science and Technology 108: 287-297.

Rolletschek H, Borisjuk L, Sánchez-García A, Gotor C, Romero LC, MartínezRivas JM and Mancha M (2007) Temperature-dependent endogenous oxygen concentration regulates microsomal oleate desaturase in developing sunflower seeds. Journal of Experimental Botany 58: 3171-3181.
Sarmiento C, Garcés F and Mancha M (1998) Oleate desaturation and acyl turnover in sunflower (Helianthus annuus L.) seed lipids during rapid temperature adaptation. Planta 205: 595-600.

SAS (2016) SAS university edition: installation guide for Windows. SAS Institute Inc., Cary, 24p.

Schulte LR, Ballard T, Samarakoon T, Yao L, Vadlani P, Staggenborg S and Rezac M (2013) Increased growing temperature reduces content of polyunsaturated fatty acids in four oilseed crops. Industrial Crops and Products 51: 212-219.

Skorić D, Jocić S, Sakac Z and Lecić N (2008) Genetic possibilities for altering sunflower oil quality to obtain novel oils. Canadian Journal of Physiology and Pharmacology 86: 215-221.

Soldatov KI (1976) Chemical mutagenesis in sunflower breeding. In Proceedings of the $7^{\text {th }}$ International sunflower conference. International Sunflower Association, Krasnodar, p. 352-357.

Turhan H, Citak N, Pehlivanoglu H and Mengul Z (2010) Effects of ecological and topographic conditions on oil content and fatty acid composition in sunflower. Bulgarian Journal of Agricultural Science 16: 553-558.

Ungaro MRG, Sentelhas PC, Turatti JM and Soave D (1997) Influência da temperatura do ar na composição de aquênios de girassol. Pesquisa Agropecuária Brasileira 32: 351-356.

Van Der Merwe R, Labuschagne MT, Herselman L and Hugo A (2013) Stability of seed oil quality traits in high and mid-oleic acid sunflower hybrids. Euphytica 193: 157-168.

Zheljazkov VD, Vick BA, Baldwin BS, Buehring N, Coker C, Astatkie T and Johnson B (2011) Oil productivity and composition of sunflower as a function of hybrid and planting date. Industrial Crops and Products 33: 537-543.

Zheljazkov VD, Vick BA, Baldwin BS, Buehring N, Astatkie T and Johnson B (2009) Oil content and saturated fatty acids in sunflower as a function of planting date, nitrogen rate and hybrid. Agronomy Journal 101: 1003-1011. 